\title{
RASISME DALAM OLAHRAGA
}

\author{
Bambang Ferianto Tjahyo Kuntjoro ${ }^{1}$ \\ ${ }^{1}$ Program Studi Pendidikan Jasmani, Kesehatan dan Rekreasi \\ FIO, Universitas Negeri Surabaya \\ Surabaya, Indonesia \\ e-mail: bambangferianto@unesa.ac.id
}

\begin{abstract}
Abstrak
Rasisme dalam dunia olahraga banyak sekali terjadi, baik di Indonesia maupun di mancanegara. Misalnya pemain kulit hitam diteriaki suporter bak "monyet", dan lainlain. Hal ini dapat mengganggu konsentrasi pemain, tetapi juga dapat mengganggu jalannya pertandingan dan dapat merusak sportivitas dalam olahraga. Rasis dalam dunia sepakbola sering muncul dalam sebuah pertandingan antarnegara atau antarklub di Eropa yang disebabkan oleh banyak faktor seperti sejarah masa lalu sebuah bangsa, ego etnis, dan adanya kesenjangan ekonomi antar dua negara.

Dengan banyaknya aksi rasisme dalam dunia olahraga, membuat organisasi-organisasi olahraga di dunia bahkan di Indonesia membuat aturan yang sifatnya membatasi dan mempersempit ruang gerak aksi rasisme bagi setiap pelaku olahraga baik pemain, pelatih, maupun supporter. Dalam Undang-Undang No. 11 Tahun 2008 Tentang Informasi dan Transaksi Elektronik ("UU ITE"), unsur dengan sengaja dan tanpa hak selalu muncul dalam perumusan tindak pidana ciber. Bunyi Pasal 28 ayat (2) UU ITE adalah sebagai berikut:Setiap Orang dengan sengaja dan tanpa hak menyebarkan informasi yang ditujukan untuk menimbulkan rasa kebencian atau permusuhan individu dan/atau kelompok masyarakat tertentu berdasarkan atas suku, agama, ras, dan antargolongan (SARA) dengan hukuman yaitu pidana penjara paling lama 6 (enam) tahun dan/atau denda paling banyak Rp1.000.000.000 (satu miliar rupiah).
\end{abstract}

Kata-kata kunci: olahraga, perpecahan, rasisme

\section{PENDAHULUAN}

Manusia terlahir di bumi ini terdiri dari bermacam-macam suku bangsa, agama, ras, dan budaya. Keragaman itu merupakan karunia yang sangat indah dari Tuhan YME. Dikatakan karunia terindah karena dengan keragaman itu manusia dapat mengenal berbagai budaya, agama, dan yang lainnya, sehingga dalam menjalani hidup manusia mempunyai banyak variasi yang dapat mengakibatkan manusia tidak mudah bosan dalam menjalani hidup. Dengan "keragaman" seperti itu juga menimbulkan perpecahan seperti kasus rasisime.
Rasisme adalah suatu sistem kepercayaan atau doktrin yang menyatakan bahwa perbedaan biologis melekat pada ras manusia, dimana suatu ras tertentu lebih superior dan memiliki hak untuk mengatur yang lainnya sehingga manusia selalu menganggap golongan, kelompok, agama, ataupun rasnyalah yang paling benar, yang paling berkuasa, dan yang lain dianggap rendah. Sedangkan, yang dianggap paling rendah kemudian memberontak yang dapat menyebabkan adanya suatu perpecahan. Oleh sebab itu rasisme dikatakan suatu pelanggaran yang cukup serius, sehingga 
memerlukan penanganan yang lebih khusus lagi. Beberapa penulis menggunakan istilah rasisme untuk merujuk pada preferensi terhadap kelompok etnis tertentu sendiri (etnosentrisme), ketakutan terhadap orang asing (xenofobia), penolakan terhadap hubungan antarras (miscegenation), dan generalisasi terhadap suatu kelompok orang tertentu (stereotipe).

Pembedaan ras sudah dimulai pada zaman Yunani kuno. Pada zaman itu fitsafat Yunani sangat berpengaruh dalam kehidupan masyarakat dunia. Plato dan Aristoteles mengemukakan ide mengenai keunggulan ras bangsa Yunani. Menurut mereka, bangsa Yunani adalah bangsa yang ditakdirkan sebagai penguasa atas bangsa-bangsa lain dan bangsa-bangsa lain tersebut sudah ditakdirkan untuk mengakui keunggulan dan diperbudak oleh bangsa yang lebih kuat. Ide ini dengan cepat menguasai konsep pemikiran orang pada zaman tersebut. Rasionalitas saat itu sangat diagung-agungkan, sehingga orang-orang beranggapan bahwa untuh meraih keberhasilan tertinggi harus memusnahkan ras-ras yang lain. Kesombongan rasial seperti ini begitu mendarah daging hingga saat ini dan menjadi suatu hal yang biasa kita jumpai hampir di seluruh belahan dunia.Selain rasio, kepercayaan terhadap mitos-mitos juga salah satu bentuk penyebab munculnya tindakan rasisme. Orang-orang tertentu percaya bahwa nenek moyang mereka berasal dari keturunan dewa-dewa dan sangat berbeda dengan golongan manusia lainnya.Kepercayaan terhadap mitos dan pengagungan rasio berdampak pada sikap beberapa golongan orang yang menganggap dirinya lebih unggul daripada orang lain. Dorongan inilah yang memicu suatu usaha menguasai dan mengendalikan ras-ras lain demi mendapatkan keuntungan bagi ras sendiri.

Sering terjadinya tindakan rasis di pertandingan sepakbola membuat FIFA turun tangan pada tahun 1990 dibentuklah Kampanye Let's Kick Racism Out of Football (Garland dan Rowe, 2001). Dalam dunia olahraga, banyak masalah yang muncul yang juga diakibatkan oleh faktor rasisme, baik di Indonesia maupun di mancanegara. Melalui tulisan ini ada beberapa hal yang ingin penulis ungkap seperti: (1) Hal krusial apakah yang terjadi dan mengapa sampai rasisme begitu pelik?; (2) Bagaimana aturan dan "win-win solution" di persepakbolaan Indonesia dan di Luar Negeri terutama badan FIFA?

\section{PEMBAHASAN}

\section{Visualisasi Olahraga dan Rasisme}

Secara umum pengertian olahraga adalah sebagai salah satu aktivitas fisik maupun psikis seseorang yang berguna untuk menjaga dan meningkatkan kualitas kesehatan seseorang. "Olahraga" datang dari bahasa Perancis Kuno "de sport" yang bermakna "kesenangan", serta pengertian berbahasa Inggris tertua ditemukan seputar tahun 1300 yakni "segala hal yang mengasyikkan serta menghibur untuk manusia". Olahraga adalah satu diantara sumber utama dari hiburan karenanya ada pendukung olahraga yang umumnya terbagi dalam beberapa besar orang dan bisa disiarkan lebih luas lagi lewat tayangan olahraga.

$$
\text { Menurut Cholik Mutohir, }
$$
olahraga adalah proses sistematik yang berupa segala kegiatan atau usaha yang dapat mendorong mengembangkan, dan membina potensi-potensi jasmaniah dan rohaniah seseorang sebagai perorangan atau anggota masyarakat dalam bentuk permainan, perlombaan/pertandingan, dan prestasi puncak dalam pembentukan 
manusia Indonesia seutuhnya yang berkualitas berdasarkan Pancasila.

Rasisme adalah suatu sistem kepercayaan atau doktrin yang menyatakan bahwa perbedaan biologis yang melekat pada ras manusia menentukan pencapaian budaya atau individu, bahwa suatu ras tertentu lebih superior dan memiliki hak untuk mengatur yang lainnya. Beberapa penulis menggunakan istilah rasisme untuk merujuk pada preferensi terhadap kelompok etnis tertentu sendiri (etnosentrisme), ketakutan terhadap orang asing (xenofobia), penolakan terhadap hubungan antar ras (miscegenation), dan generalisasi terhadap suatu kelompok orang tertentu (stereotipe)

\section{Sejarah Rasisme}

Terlahir sebagai manusia dengan ciri-ciri fisik, seperti warna kulit hitam, hidung pesek, dan rambut keriting haruslah diakui bukan sebagai satu kesalahan atau "dosa turunan". Manusia mana pun tak pernah punya pilihan ketika dilahirkan, termasuk lahir dengan kondisi "cacat secara fisik". Semua itu semata-mata merupakan takdir Tuhan. Artinya, bentuk fisik dan warna kulit manusia adalah hak prerogatif Tuhan yang tak bisa ditolak. Sebaliknya, keragaman dan perbedaan warna kulit itu harus dipahami sebagai kemajemukan ras, bukan menunjukkan satu superioritas. Sebab semua manusia diciptakan Tuhan setara dan dianugrahi hak-hak individu yang berasal dari alam dan akal.

Rasisme dalam sejarahnya selalu menjadi hantu ideologi sosial yang menyebalkan dan menjijikkan, sampai sekarangpun, rasisme rasanya masih berupa ketegangan upaya dalam mengucap eksistensialitas diri dan kelompok lebih baik daripada yang lain. Dengan kata lain ini menyangkut persoalan identitas, biologis dan optimasi fisik yang dipandang lewat kacamata perspektif diri sendiri. Dan parahnya itu menjadi faham, diteriakkan tanpa mempunyai rasa malu dengan membayangkan ideologi yang ada dibelakang mereka sebagai satu kekuatan superpower yang mampu meluluhlantakkan apapun yang menghalangi jalannya.

\section{Pemicu Rasisme}

Seru dan asyiknya putaran AFF Cup 2012 bertambah bumbu sehingga rasanya bertambah pedas. Bumbu yang ditambahkan itu adalah (1) pengeroyokoan suporter Indonesia oleh suporter Malaysia di Kuala Lumpur, Malaysia. (2) Publik Indonesia dan Singapura dikejutkan dengan unggahan video di www.youtube.com yang berbau rasis. Dalam tayangan itu, tergambar suporter Malaysia bernyanyi dengan syair yang melecehkan Indonesia dan Singapura. Apa yang dilakukan oleh suporter Malaysia tentu memancing respon yang negatif dari rakyat Indonesia. Pasti akan ada pembalasan dari suporter Indonesia dan Singapura dalam sebuah moment yang akan datang.

$\begin{array}{ccr}\text { Rasis dalam dunia } & \text { sepakbola } \\ \text { sering muncul dalam } & \text { sebuah }\end{array}$ pertandingan antarnegara atau antarklub di Eropa. Rasis muncul di sepakbola Eropa disebabkan oleh banyak faktor seperti sejarah masa lalu sebuah bangsa, ego etnis, dan adanya kesenjangan ekonomi antar dua negara. Rasis selalu muncul dalam Piala Eropa bila yang bertanding el-clasico atau bebuyutan, seperti Inggris melawan Jerman dan Belanda melawan Jerman.

Saat Perang Dunia II, Jerman melakukan penyerbuan ke banyak negara di daratan Eropa dengan menggunakan taktik Blitzkrieg atau perang kilat. Blitzkrieg selain kilat juga 
menggunakan kekuatan penuh yakni mengerahkan kekuatan pesawat terbang, tank, dan artileri. Dengan kekuatan yang ada kekuatan itu menerobos pertahanan musuh menyusuri front yang sempit. Sedang kekuatan udara menghalangi musuh untuk menutupi celah pertahanan yang lowong. Dengan taktik ini Jerman mengepung pasukan lawan dan memaksa mereka untuk menyerah.

\section{Rasisme dalam Olahraga Sepakbola}

Menurut Kamus Besar bahasa Indonesia rasisme diartikan sebagai paham atau golongan yang menerapkan penggolongan atau pembedaan ciriciri fisik (seperti warna kulit) dalam masyarakat. Rasisme juga bisa diartikan sebagai paham diskriminasi suku, agama, ras (SARA), golongan ataupun ciri-ciri fisik umum untuk tujuan tertentu. Tujuan tertentu itu jelas bermakna sangat merugikan bagi si korban. Sangat disayangkan itulah yang terjadi dalam dunia sepakbola Indonesia dan mancanegara.

\section{Rasisme Persepakbolaan Mancanegara}

Cabang olahraga paling populer di muka bumi ini pernah dinominasikan menjadi salah satu kandidat penerima Hadiah Nobel Perdamaian 2001 oleh Akademi Swedia. Menurut International Herald Tribune, sepak bola dipilih karena dinilai bisa menjembatani saling pengertian antarbudaya.Pilihan Akademi Swedia itu sebenarnya tak keliru. Anggaran Dasar Federasi Sepak Bola Internasional (FIFA) pun telah mengasaskan hal yang sama. Menurut anggaran dasar itu, sepak bola bertekad menjadi sarana melunturkan semua prasangka.

\section{2. "Ku Klux Klan" Masuk Stadion}

Tak hanya masyarakat sepak bola Norwegia yang mengambil langkah. Dua pekan lalu, pada 16 Maret 2015, England's Member Club, sebuah kelompok fans sepak bola, dinyatakan terlarang oleh Pemerintah Inggris. Kelompok dengan anggota sekitar 30.000 orang ini dinilai selalu mengampanyekan "huliganisme" dan rasisme setiap melawat ke luar negeri menemani tim nasional (Bonnett, 2000).

\section{Monyet Hitam vs Gipsi Sialan}

Arrigo Sacchi tahu persis apa yang dialami kedua pemainnya itu. Penggemar sepak bola mana pun tahu, betapa Rijkaard dan Gullit telah menyuguhkan permainan sepak bola kelas satu kepada publik Italia. Sacchi tak habis mengerti, mengapa kedua pemain Belanda berkulit hitam asal Suriname itu masih selalu mengalami perlakuan rasis yang kasar di stadionstadion sepak bola Italia."Di stadionstadion kami, budaya olahraga nyaris tak lagi tersisa," kata Sacchi. Tak hanya Sacchi yang merasakan atmosfer rasisme yang buruk di stadionstadion Italia. Persatuan Sepak Bola Inggris, FA, malah secara resmi pernah mengajukan protes keras pada UEFA, atas perlakuan yang diterima salah satu pemainnya di Stadion Delle Alpi di Turin (Bonnett, 2000).

\section{Klub Diktator Mussolini}

Pendukung klub Lazio memang sudah lama dikenal sebagai kubu paling rasis di antara seluruh kubu pendukung klub-klub Seri A di Liga Italia. Maklum saja, dulu klub ini adalah klub kecintaan diktator Italia, Benito Mussolini. Tak mengherankan bila pendukung fanatik kesebelasan ini enak saja menghina pemain Lazio yang menurut mereka tak pantas mewakili klub kesayangannya. Aron Winter, pemain nasional Belanda, adalah pesepak bola kulit hitam terakhir yang bermain bagi Lazio. Ketika pada 1992 Aron Winter datang ke Lazio, ia 
disambut sebuah spanduk besar yang dengan sangat menghina menyebutnya "Yahudi Negro". Para pendukung Lazio ini jelas tak cukup mengenal Winter. Ia sama sekali bukan Yahudi, sebab nama tengahnya adalah Mohammed.

\section{Kebangkitan Fasisme dan Kaum Ultrakanan}

Sungguh sayang jika semangat berkompetisi hancur karena perbuatan tak terpuji," kata Paus. Toh, ada yang menganggap kekhawatiran terhadap kebencian rasial ini terlalu berlebihan. Salah satunya adalah Dino Zoff mantan kiper legendaris Italia yang kini melatih Lazio. Musim lalu, sebagai Asisten Presiden Lazio, Zoff terpaksa membayar denda akibat aksi pendukung klubnya.Lazio didenda US\$ 2.250 karena Irrudicibili melakukan pelecehan terhadap Bruno N'Gotty, pemain belakang berkulit hitam yang bermain untuk Venesia. "Saya tak tahu, apakah hal seperti itu bisa disebut rasisme," katanya, "Ini kan cuma cara sekelompok orang membuat lelucon. Mereka bisa saja memilih orang yang terlalu tinggi, terlalu pendek, atau berkulit hitam.

\section{Kawasan Tanpa Kulit Berwarna}

Dalam sebuah cerita sampulnya pada 1994, time mencatat betapa bagi kaum neofasis, sepak bola merupakan lahan paling efektif untuk merekrut anggota baru. Hal ini, menurut Time, paling jelas terjadi di Inggris. Di Spanyol, para pemuda ultrakanan juga menggabungkan kekerasan jalanan dan lambang-lambang neo-Nazi dengan dukungan bagi tim kesayangan mereka. Di Prancis adalah Jean Marie Le Pen, politisi ultrakanan, yang mengucapkan kata-kata kasar ketika "Les Bleus", tim sepak bola nasional Prancis untuk Piala Dunia 1998, dibentuk dari pemainpemain yang multiras. "Tim masyarakat pendatang ini tak pantas mewakili Prancis," kata Le Pen. Toh, hasilnya, tim ini merebut Piala Dunia Sepak Bola 1998, dan juga Piala Eropa 2000.

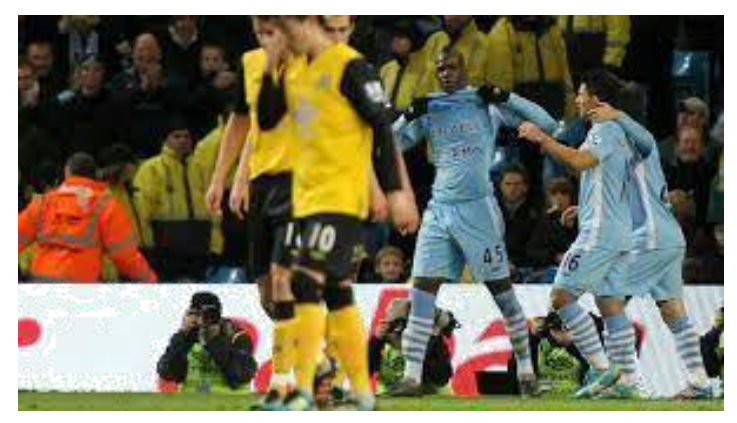

Gambar 1. Kasus Rasisme dalam Sepakbola

Representasi anti rasisme selebrasi Mario Balotelli ditunjukkan melalui gestur dan mimik wajah yang minimalis. Anti rasisme yang dilakukan Balotelli digambarkan sebagai perlawanan secara damai karena ia melakukannya tanpa membuat keributan, menyakiti orang lain secara fisik maupun secara verbal dan tidak memancing tim/suporter lawan untuk melukainya. Selain itu, selebrasi yang dilakukan Balotelli tidak melanggar batasan selebrasi yang sudah diatur oleh Fédération Internationale de Football Association (FIFA) yaitu membuat olokan gerakan tubuh yang provokatif, menaiki pagar pembatas, dan meninggalkan lapangan terlalu lama.

Menyerukan pesan anti rasis dengan damai merupakan salah satu cara yang efektif karena ras kulit hitam sendiri sering mendapat stereotip sebagai kriminal, kasar, jahat, bahkan berani membunuh (Jismulatif, 2009). Representasi anti rasisme selebrasi tersebut juga menyampaikan makna untuk melakukan perlawanan kejahatan tidak perlu menggunakan kejahatan pula. Seperti yang diketahui bahwa ras kulit hitam telah mendapat banyak kekerasan baik secara verbal maupun fisik (Franz, 2008), namun melalui selebrasi ini Balotelli berhasil 
"membalas" mereka tanpa menggunakan kekerasaan.

Selain itu, selebrasi why always me ini mengandung sifat oposisi biner dimana selebrasi ini berlawanan dengan selebrasi yang dilakukan pemain sepak bola lainnya. Selebrasi Balotelli ini direpresentasikan sebagai selebrasi anti rasisme yang damai dan tenang berbeda dengan selebrasi yang dilakukan Paolo di Canio dimana ia menunjukkan bahwa dirinya seorang fasis. Selebrasi Paolo di Canio ini kemudian menimbulkan keributan dan kontroversial bahkan hingga saat ini (Maniglio, dalam Junaedi, 2017).

\section{Kesepakatan PBB}

Di Budapest, Hongaria, tatkala Ajax Amsterdam menghadapi klub Ferencvaros dalam kompetisi sepak bola Eropa, stadion itu penuh teriakan, poster, dan umpatan rasis, setiap pemain berkulit hitam Ajax memainkan bola. Menurut Tamas Krausz, sejarawan Hongaria, dalam Soccer and Racism in Hungary, atmosfer rasis di stadionstadion Hongaria tak punya akar dalam sejarah (Liliweri, 2018).

\section{Rasisme Persepakbolaan di Indonesia}

Dimulai dari persepakbolaan Indonesia, sikap rasisme bisa dipastikan terjadi di setiap pertandingan Liga Indonesia yang digelar. Awal dari Liga Indonesia 2007 saja dinodai dengan aksi rasisme yang diluncurkan terhadap pemain Persipura. Selain kejadian itu, tindakan rasisme kali ini menimpa mantan pemain Persib yang kini membela Arema malang yakni Alexander Pulalo yang mengalami dua kali perlakuan rasisme. Pada tanggal 25 Maret 2007 tepatnya hari Minggu di Stadion Gelora Delta, Pulalo mendapatkan perlakuan tidak berkenan dari pendukung Deltras dan pada hari Rabu tanggal 28 Maret 2007 dari para pendukung PSIM di Stadion Mandala Krida Yogyakarta.

\section{Penolakan Rasisme dan Geliat}

Isu rasialisme terus menjadi perhatian dan problem yang berupaya diatasi di dunia sepakbola. Macammacam caranya. Borussia Dortmund misalnya, berkampanye anti rasialisme lewat satu juta tatakan gelas bir. Dortmund baru-baru ini memulai kampanye melawan kekerasan rasialisme dengan mengambil tema unik: 'Kein Bier fur Rassisten!' atau dalam bahasa Indonesia berarti 'Tak Ada Bir untuk Rasialis!'. Mereka menyebar satu juta tatakan bir dengan slogan tersebut ke berbagai bar lokal di kota Dortmund Jerman. Kampanye ini jadi lanjutan langkah tegas Die Borussen terhadap tindakan-tindakan rasialisme, juga berupaya meredam aksi-aksi ekstrem berhaluan politik kanan jauh seperti fasisme. Mereka sebelumnya juga diketahui menjatuhkan hukuman berat, yakni larangan ke stadion selama empat tahun untuk salah seorang penggemar yang melakukan salam Nazi. Kota Dortmund sendiri yang berpopulasi hampir 600 ribu jiwa memang dikenal sebagai salah satu basis gerakan politik sayap kanan di Jerman.

\section{Rasisme dan Hukuman}

Dalam Undang-Undang No. 11 Tahun 2008 Tentang Informasi dan Transaksi Elektronik ("UU ITE"), unsur dengan sengaja dan tanpa hak selalu muncul dalam perumusan tindak pidana siber. 'Tanpa hak' maksudnya tidak memiliki alas hukum yang sah untuk melakukan perbuatan yang dimaksud. Alas hak dapat lahir dari peraturan perundang-undangan, perjanjian, atau alas hukum yang lain. 'Tanpa hak' juga mengandung makna menyalahgunakan atau melampaui wewenang yang 
diberikan. Perbuatan yang dilarang dalam Pasal 28 ayat (2) UU ITE ialah dengan sengaja dan tanpa hak menyebarkan informasi yang ditujukan untuk menimbulkan rasa kebencian atau permusuhan individu dan/atau kelompok masyarakat tertentu berdasarkan suku, agama, ras, dan antargolongan (SARA).

Bunyi Pasal 28 ayat (2) UU ITE adalah sebagai berikut:Setiap Orang dengan sengaja dan tanpa hak menyebarkan informasi yang ditujukan untuk menimbulkan rasa kebencian atau permusuhan individu dan/atau kelompok masyarakat tertentu berdasarkan atas suku, agama, ras, dan antargolongan (SARA).

Ancaman pidana dari Pasal 28 ayat (2) UU ITE tersebut diatur dalamPasal 45 ayat (2) UU ITE yaitu pidana penjara paling lama 6 (enam) tahun dan/atau denda paling banyak Rp1.000.000.000 (satu miliar rupiah).

\section{Dasar Hukum PSSI}

Pasal 59 Peraturan Organisasi

PSSI tentang Kode Disiplin PSSI menjelaskan tentang tingkah laku buruk melakukan tindakan rasis.Ayat (1) Siapapun yang melakukan tindakan rasis berupa tingkah laku buruk, diskriminatif atau meremehkan seseorang atau melecehkan seseorang dengan cara apapun dengan tujuan menyerang atau menjatuhkan nama baik orang tersebut yang terkait dengan pertandingan, warna kulit, bahasa, agama atau suku bangsa atau melakukan tindakan rasis melainnya dengan cara apapun, dijatuhi hukuman larangan ikut serta dalam pertandingan paling tidak 5 (lima) kali di setiap jenjang pertandingan dan denda paling sedikit Rp 300.000.000 (tiga ratus juta rupiah).

\section{H. Peraturan FIFA}

Teks asli"Discrimination of any kind against a Country, private person or group of people on account of race, skin colour, ethnic, national or social origin, gender, language, religion, political opinion or any other opinion, wealth, birth or any other status, sexual orientation or any other reason is strictly prohibited and punishable by suspension or expulsion".

Kongres Luar Biasa FIFA, pertemuan di Buenos Aires pada tanggal 7 Juli 2001, sesuai dengan Statuta FIFA, dan mewakili semua Asosiasi dan National Kontinental Konfederasi dalam badan sepak bola dunia. Berisi klausul :Setelah mempertimbangkan istilah "rasisme" dalam konteks saat ini untuk menerapkan terutama untuk tindakan diskriminasi berdasarkan atas semua, tidak eksklusif, pada perbedaan antara individu manusia atas dasar warna kulit dan asal-usul etnis.

FIFA menyepakati langkah baru dalam menangani rasisme dengan sanksi bagi tim sepak bola termasuk relegasi atau dikeluarkan dari liga bila terlibat dalam insiden serius. Yang berisi tentang : (1) Pelanggaran pertama atau minor akan menghadapi peringatan, denda atau pertandingan di stadion tertutup. (2) Tim-tim yang terus melakukan pelanggaran dapat menghadapi hukuman pengurangan poin, pencoretan dari liga atau relegasi.

Jeffrey Webb, kepala gugus tugas antirasisme FIFA, mengatakan keputusan itu merupakan "saat yang menentukan. Ia menambahkan, "Keluarga sepak bola menyadari apa yang dilaporkan media hanyalah kurang dari $1 \%$ insiden yang terjadi di seluruh dunia.""Kami harus mengambil langkah ini sehingga bila kita tilik 20 sampai 50 tahun mendatang, saat ini adalah waktu yang menentukan bahwa kita telah 
mengambil langkah menentang rasisme dan diskriminasi" (Mangan dan Ritchie, 2004).

Pada dasarnya semua federasi bidang olahraga termasuk sepak bola sudah mulai membuat aturan tentang diskriminasi dan rasisme, hal ini bertujuan untuk meminimalisir terjadinya aksi-aksi rasialisme dan diskriminatif yang dapat merusak konsentrasi pemain, jalannya pertandingan, maupun aksi kekerasan diluar lapangan.

\section{SIMPULAN DAN SARAN Simpulan}

Arti Olahraga adalah aktivitas untuk melatih tubuh seseorang, tidak hanya jasmani tetapi juga rohani, dan bertujuan untuk mencapai prestasi yang setinggi-tingginya akan tetapi banyak orang menjadikan olahraga menjadi milik golongan tertentu dan menjadikan mereka menjadi seseorang yang bisa disebut rasisme yang dapat diartikan sebuah kepercayaan atau doktrin yang menyatakan bahwa perbedaan biologis yang melekat pada ras menentukan pencapaian budaya atau individu bahwa suatu ras tertentu lebih superior dan memiliki hak untuk mengatur yang lainya hal tersebut juga sebagai paham diskriminasi suku, agama, ras (SARA). Oleh sebab itu dalam organisasi olahraga membuat sebuah aturan-aturan mengenai diskriminasi dan rasisme untuk melindungi pelaku olahraga dalam melaksanakan perannya, sehingga jalannya pertandingan menjadi lancar, tidak ada perpecahan dalam satu Negara, dan tidak adanya kerusuhan supporter yang terjadi.

\section{Saran}

Beberapa saran yang dapat diusulkan :

1. Untuk pemain, sebagai seorang pemain harus mengamati teman satu tim atau lawannya tanpa meremehkan dari sisi warna kulit, tinggi badan, ras, ataupun kemampuannya dan ikut mendukung anti rasisme

2. Untuk pelatih dan manajemen tim, tidak membeda-bedakan pemainnya

3. Untuk supporter,tujuan suporter adalah untuk menyemarakkan sebuah pertandingan, suporter seharusnya tidak perlu untuk melecehkan seorang pemain atau sebuah tim, cukup membela tim yang diharapkan karena jika melakukan penghinaan bukan saja mengganggu pertandingan tetapi juga mengakibatkan kerusuhan.

4. Untuk induk organisasi, membuat aturan yang sifatnya mempersempit ruang gerak bagi pelaku diskriminatif dan rasisme dalam olahraga yang berupaya membuat efek jera bagi pelaku olahraga

Bagi semua pelaku olahraga baik itu pemain, supporter, pelatih, manajer, dll hendaknya menyadari bahwa rasisme itu adalah suatu perbuatan yang dapat mengakibatkan perpecahan, dan hal itu sangat menyakitkan bagi korban akibat pelecehan rasisme. Oleh sebab itu "Let's Kick Racism Out of Our Life" singkirkan rasisme dari kehidupan kita. Dan juga bagi pihak-pihak berwenang hendaknya member sanksi yang tegas bagi pelaku rasisme, mengingat dampak yang ditimbulkan akan sangat berbahaya.

\section{DAFTAR PUSTAKA}

\section{-------. 2006. Hukuman Berat Bagi Pelaku Rasisme. (Online), (http://www.suaramerdeka.com/ha rian/0608/02/ora19.htm, diakses pada 17 April 2015).}


2007. Rasisme dalam Sepakbola. (Online),

(http://athos666.multiply.com/jour nal/item/5/Rasisme_Dalam_Sepak _Bola.html, diakses pada 17 April 2015).

------. 2008. Rasisme dalam Kaitan Olahraga Di Eropa.(Online), (http://www.antara news.com/article/2007/rasismedalam-kaitan-olahraga-dieropa/opi07.html, diakses pada 17 April 2015).

-------. 2008. Rasisme di Stadion Sepakboa. (Online), (http://www.dwworld.de/dw/article/0,,3379993,00 .html, diakses pada 17 April 2015)

------. 2009. Rasisme. (Online), (http://id.wikipedia.org/wiki/Rasis me, diakses pada 17 April 2015).

------. 2013. Sanksi Rasisme FIFA Termasuk Relegasi. (Online), (https://www.bbc.com/indonesia/o lahraga/2013/05/130531_fifareleg asi_rasisme, diakses pada 28 April 2020).

Bonnett, Alastair. 2000. Anti-Racism. London: Routledge

$\begin{array}{cl}\text { Burgoon,Judee } & \mathrm{K} ; \quad \text { Saraine, } \\ \text { Thomas. } & \text { 1978. The } \\ \text { Unspoken } & \text { dialogue: an }\end{array}$ introduction to nonverbal communication. London:

Houghton Mifflin.

Dwi Cahyo. 2008. Penjas, Olahraga, atau Bermain Ya?. (Online), (http://onopirododo.wordpress.co $\mathrm{m} / 2008 / 11 / 14 /$ pendidikanjasmani-olahraga-atau-bermainya/, diakses pada 03April 2015).

Garland, Jon; Rowe, Michael. 2001. Racismand Anti-
Racism in Football.Wiltshire: Palgrave.

Gigie, Deu'. 2009. Rasisme dalam Dunia Sepakbola. (Online), (http://deugigie.blogspot.com/200 9/03/rasisme-dalam-duniasepakbola.html, diakses pada 17 April 2015).

Irab, Yenita. 2007.Rasisme. 5(1): 50-58.

Jismulatif. 2009. Studi Tentang Rasialisme dalam Film The Green Mile. Jurnal Ilmu-Ilmu Sejarah, Buday, dan Sosial. 1 (2).

Junaedi, Fajar, 2017. Merayakan Sepak Bola: Fans, Identitas, dan Media Edisi 2. Yogyakarta: Fandom.

Liliweri, Alo. 2018. Prasangka, Konflik, dan Komunikasi Antarbudaya. Jakarta: Kencana.

Mangan, J.A; Ritchie, Andrew. 2005. Ethinicity, Sport, Identity. London: Frank Cass Publisher

Mursidi, Nur. 2006. Menelusuri Jejak Rasisme. (Online), (http://www.sinarharapan.co.id/be rita/0605/20/opi06.html, diakses pada 17 April 2015).

Pratama, Wahyudi. 2005. Menyikapi Rasisme. (Online), (http://firstthings-

first.blogspot.com/2005/09/menyi kapi-rasisme.html, diakses pada 17 April 2015).

Rachim, Angga Aulia. 2007. Definisi Olahraga??. (Online), (http://anggaauliarachim.wordpres s.com/2007/10/24/23/, diakses pada 03 April 2015). 